\title{
Who decides on what to spend in CSR? Moving from compulsion to consensus
}

\author{
Jagannath Mohanty \\ Institute of Management Technology, Nagpur, India \\ Email address: \\ jmohanty@imtnag.ac.in
}

To cite this article:

Jagannath Mohanty. Who Decides on What to Spend in CSR? Moving from Compulsion to Consensus. International Journal of Economic Behavior and Organization. Vol. 2, No. 2, 2014, pp. 13-19. doi: 10.11648/j.ijebo.20140202.11

\begin{abstract}
With CSR spending becoming mandatory in some prominent economies, quantum of spend is increasingly becoming a non issue. Instead spending right has acquired prominence. Ever since policy makers mulled the idea of making CSR spending compulsory, there appears to be rush and panic in the business world to spend on CSR activities that gives them the best return on their social investment. The debate is on for decades now, as to who should decide on what to spend and how much? For long in the name of CSR activities businesses have been spending on initiatives that were either a part of owner's choice or were easy to identify and implement, mostly avoiding the views of stakeholders inside as well as outside. This paper attempts to address broadly the issue of stakeholder confidence and preference in a CSR initiative. The paper suggests a model of engagement of stakeholders both within and outside of a business for the roll out of a CSR initiative.
\end{abstract}

Keywords: Corporate Social Responsibility, Stakeholder Theory of Firm

\section{Introduction}

Businesses have long been managed by a powerful shareholder-oriented objective, stating that management must maximise economic returns. According to this doctrine, corporate responsibilities are merely legal and economic in nature. During recent years, however, this paradigm has been losing strength to the concept of corporate social responsibility (CSR). Nowadays, society at large increasingly expects companies to behave as good corporate citizens. Hence, the company's responsibilities are not limited to making profit and creating employment. Businesses are also responsible for the well-being of a broader group of stakeholders, such as employees, consumers, suppliers and society at large. Spending is just the one side of the coin. The other and perhaps more pertinent is measuring the impact of spends whether huge or small. Time and again the debate surfaces about legitimacy of CSR spending.

Corporate Social Responsibility (CSR) classically described as the concept that business has an obligation to society that extends beyond its narrow obligation to its owners or shareholders (Bowen, 1953), has generally been promoted as voluntary (McGuire, 1963; European Commission, 2001; Commission of the European
Communities, 2006). The dominant argument is that the desire of organisations to maintain legitimacy is sufficient to promote CSR (Tuzzolino and Armandi, 1981; Powell and DiMaggio, 1991; Elsbach, 1994).

Some writers contend that CSR is akin to promotion of fundamental human rights e.g. right to property, dignity of labour and good livelihood, and thus ethically necessary, morally obligatory and within the sphere of compulsory regulation (Utting, 2005; Wettstien, 2009). Compulsory regulation refers to legislative enactments or judicial judgements prescribing roles and sanctions. The advocacy for compulsory regulation is seen as a sure way to promote transparency and accountability and also regain the trust of the public (Muller, 2010; Shaxson, 2009; Pritchard, 2003). This is because evidence has shown that when companies and government are left unchecked they do become oppressive and irresponsible [Enron, the recent BP spillage crisis] (Pritchard, 2003). Compulsory regulation also has the benefits of certainty, enforceability (Gatto, 2002), fair play and stakeholder empowerment (DBIS, 2009). In stakeholder engagement, compulsory regulation will define duties, provide for the rights of parties, and create order and predictability in procedure (Gatto, 2002). Compulsory regulation is usually universal (covering the entirety of the identified population). This universality and enforcement 
feature is what ensures the right of aggrieved parties to seek remedy and deters deviance.

At the same time scholars contend that compulsory regulation has its limitations. These include high cost (Glaser and Gyourko 2002), difficulty of access to justice and procedural requirements. There is also lack of court precedents to rely on because few CSR cases have been conclusively decided in courts of law. Another limitation is the reactive nature of regulation. Laws are generally unable to anticipate some situations. They are written, or in the case of court judgements reached in retrospect or reactive instead of proactive (Ward 2000, 2002; Gatto 2002; Pritchard, 2003). There are also drafting complexities arising from tokenism and inelegant attempts to pacify lobbyists (Arnstein 1969). However, despite these seeming limitations, there appears to be more support for compulsory regulation for its potential to create trust and fairness in business relations (Muller, 2010; Shaxson, 2009; Pritchard, 2003).The question, however, is can it work for Corporate Social Responsibility? The term corporate social responsibility (CSR) first appeared within the context of business studies in the mid 1960s. Subsequently, the notion of responsibility, traditionally attached to individuals, started to be widely applied to companies (Epstein 1989; French 1984; Soares 2003).

Moreover, it became clear that the CSR paradigm is not only the final result of a process, but also a process itself that must be considered in all decision making, as well as evaluated and measured (Jones, 1980, refer table 1). Today, CSR is focused on a stakeholder model, which has become widely accepted among contemporary business organisations. Nevertheless, it is extremely dynamic, in that stakeholders change as the company's context of reference changes (Dunfee, 1991; Hasnas, 1998). This new perspective stresses the importance of inter-stakeholder relationships, which involve a complex web of relationships rather than just a series of dyadic connections between stakeholders and the corporation. Crucial questions still are who the relevant stakeholders are and what influence they have on CSR spending avenues and investment decisions.

Although the stakeholder concept can be approached from many sides (Phillips et al. 2003), its connection with management decision-making is an important underlying principle (Jones \& Wicks 1999). From this perspective, effective management of the firm's relationships with societal actors is a primary concern. According to Carrol \& Bucholtz (cited in Keijzers 2003: 108), stakeholder management centres around three equally important questions: 'What stakeholders need to be dealt with? What form should the relationship with a stakeholder take? And how should stakeholder management be linked to internal processes?' It is proposed that firms can manage their relationships with societal actors in two (rather extreme) ways: an 'inside-out' and an 'outside-in' perspective. Firms that operate from a particular perspective will define their responsibilities towards society differently. However, these two positions are extremes of a theoretical continuum. In practice, firms might adopt various positions in between and shift from one perspective to the other.

\section{The Review of Literature}

Wood (1991) suggests that the public responsibility of business is divided into areas of social involvement directly related to their business activities and competencies, with secondary areas of involvement relating to its primary activities. For example, an auto maker might reasonably be expected to deal with vehicle safety and the environment but not low-income housing or adult illiteracy. Clarkson's long-term study of corporate behaviour (Clarkson, 1995) indicates that companies deal with stakeholders, not society, and that CSR must distinguish between stakeholder needs and social issues; managers can address stakeholder requirements but not abstract social policy. Carroll (1979, 1991) suggests corporate responsibility has different layers: economic, legal, ethical and discretionary categories of business performance and those business leaders must decide the layer at which they choose to operate.

Stakeholders, acting either formally or informally, individually, or collectively, are a key element in the firm's external environment that can positively or negatively affect the organisation (Murray and Vogel, 1997, p. 142) Underpinning the difficulties of managing the relationship between a business and its stakeholders are issues such as: divergent and often conflicting expectations between stakeholders (Bowmann-Larsen and Wiggen, 2004; Brammer and Pavelin, 2004, p. 706; Castka et al., 2004; Deresky, 2000; Fairbrass, 2006; Greenfield, 2004; Murray and Vogel, 1997); contextual complexities (CSR Risk Mapping Initiative, 2004; Daniels and Radebaugh, 2001) that are further complicated by varying interpretations arising out of different geographical regions and cultures (Castka et al., 2004; Deresky, 2000; Epstein and Roy, 2001; Fairbrass, 2008; Maignan et al., 2002; Maignan and Ferrell, 2003; Woodward et al., 2001); the challenge of identifying what might be considered to be 'best practice' with regard to CSR stakeholder dialogue strategy and then communicating this to stakeholders (Weiss, 1998). When attempting to manage these challenges, CSR stakeholder dialogue can be seen as a key vehicle for the "exchange" of CSR offerings between the firm and its stakeholders (Murray and Vogel, 1997, p. 142). This exchange is one in which the firm offers something of value (typically a social benefit or public service) to an important constituency and, in turn, anticipates receiving the approval and support of key individuals and/or socio-political groups in its environment (Fairbrass, 2006, 2008; O'Riordan and Fairbrass, 2006). The discussion immediately above indicates why it may be appropriate for managers to look to the firms' constituencies and stakeholders when approaching strategic CSR-planning activities (Murray and Vogel, 1997, p. 142), and how stakeholder dialogue plays a vital part in the development of CSR and other operational 
business strategies. Previous analytical frameworks Having outlied in brief some of the basic issues arising from the terms and concepts used in this paper, we now turn to exploring in more detail some of the key contributions to the literature on CSR and stakeholder dialogue.

Of particular merit in this literature is the suggestion that five dimensions of corporate strategy may be particularly critical to the success of the firm and useful in relating CSR policies, programmes, and process to 'value creation'. Those dimensions include 'centrality', 'specificity', 'reactivity', 'voluntarism', and 'visibility' (Burke and Lodgsdon, 1996, pp. 496-497). However, whilst this approach is comprehensive, the relationships between the elements could be better developed and the practices portrayed in more specific detail. In addition, we find Hofstede's (1997) and Trompenaar and Hampden-Turner's (2004) work on culture to be relevant to the discussion about CSR and stakeholder dialogue practices, particularly when examining the behaviour of large multi-national businesses, such as pharmaceutical companies. Ideas about 'people' and 'events', and theories about 'values', 'strategy alternatives', and 'response models' we also find to be significant in this context. Similarly, notions about 'communication' within CSR, as well as ideas about 'control indicators' (Welford, 2004, 2005) and 'managing goodwill, image and reputation', and the 'process of how to execute stakeholder analysis' (Weiss, 1998, pp. 33-44) are also valuable.

\section{Method and the Model}

Perhaps one of the most influential and powerful model in the CSR and Corporate Governance is the Stakeholder's theory. Ever since Freeman (1984) defined stakeholders as 'any group or individual who can affect or are affected by the achievement of the firm's objectives', scholars have provided all kinds of possible interpretations of the theory. Stakeholder theory has increasingly become the common frame of reference when CSR is discussed. According to the stakeholder model, a company must be aware of and respond to the various demands of its constituents, including employees, customers, investors, suppliers, and the local community(Post and Sachs, 2002). Thus, it breaks with the notion that the shareholders are the only important constituents and that shareholder wealth is the only relevant criteria for evaluating company behavior. One of the reasons is that the clear-cut distinction between "social" and "economic" does not hold up in reality (Harrison and Freeman, 1983).

The conceptual model envisaged therefore takes the stakeholder's theory as the point of reference because scholars convincingly argue that stakeholders theory compels the firms to invest in CSR programs (Argandona, 1998; Freeman, 1984; Harvey and Schaefer, 2001; Post, 2003). Stakeholder theory and CSR activity have been linked (Ullmann, 1985) by demonstrating that there exists an interrelationship between social disclosure and social and economic performance.

Occasionally stakeholder theory has been criticized as "ambiguous" (Pesqueux, 2006) and has "so far had little to say about how managers and other decision makers in business are made aware of morally significant relationships" (Palmer \& Stoll, 2011).

However, taking the body of literature as a whole we contend that it provides a fragmented patchwork of ideas and concepts. None of the approaches is sufficient in its own right in providing a comprehensive framework (O’Riordan and Fairbrass, 2006).

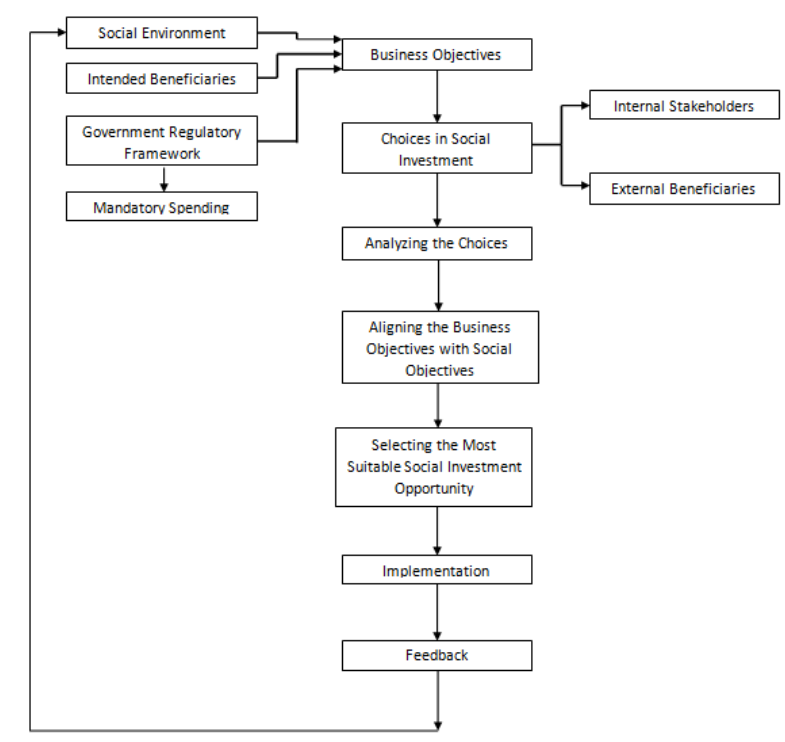

Figure 1. The Conceptual Model.

The model suggested (Figure 1) is based on the outside in perspective of the firm. Outside-in perspective firms adopt an outside-in perspective to CSR are located at the other end of the continuum; firm's social responsibilities are defined by its stakeholders' claims, rather than by the firm itself. This position bears a close resemblance to a 'traditional' stakeholder management approach. The traditional stakeholder approach largely involves scanning the environment for societal demands - often expressed by formal organizations - and responding to these demands in an acceptable manner. The widely cited article by Mitchell et al. (1997) is demonstrative of this approach. These authors have identified three criteria to prioritise stakeholders: (1) the stakeholder's power, (2) the legitimacy of the stakeholder and (3) the urgency of its claim. Essentially, Mitchell et al. posit that the higher a particular stakeholder scores on these criteria, the more salient this stakeholder is to the firm. In the end, organisations that wish to preserve their licence to operate must focus on powerful and legitimate stakeholders presenting urgent claims. Power and urgency are tangible criteria that companies use to assess claims or risks that might endanger the company (or its reputation) in the short run. Legitimacy, the third and most complex criterion that Mitchell et al. mention, is often overlooked in stakeholder 
analyses. If power and urgency are used as key criteria for identifying and managing stakeholders, the process turns into a risk assessment instead of a method to understand and weigh stakeholders' expectations relating them to the company's competencies and (long-term) goals. Other authors have also developed the argument that organisations must focus on salient stakeholders. For example, Clarkson (1995) argues that organisations must concentrate on their primary stakeholders, those groups and individuals who are critical to the organisation's survival. Rowley (1997) argues that firms do not merely face individual stakeholders, but are confronted with stakeholder networks. He posits that the firm's power relative to its stakeholders is derived from characteristics of the stakeholder network.

The inherent inadequacy of the inside out approach has been excess linkage to firm's objectives. Even though inside-out position allows firms to develop a long-term and coherent CSR policy that is strongly embedded in the organization, so that the firm's societal activities will result in a well-coordinated CSR policy. Nevertheless, some have argued that defining the firm's social responsibility from an inside-out perspective suffers from inherent difficulties. For example, Crane \& Matten (2004) argue that the identification of a firm's responsibility is, in many aspects, arbitrary. Maclagan (1999) even states that it is in general impossible to define corporate responsibility in terms of specific outcomes. Even though one might claim that businesses have general responsibilities for preventing pollution or the use of child labour, specific circumstances might affect the firm's responsibilities fundamentally.

The model envisages a three pronged input in formulation of firm's CSR objectives. The model proposes a three input sources namely social environment, intended beneficiary and the regulatory framework. It is assumed that these are the ubiquitous sources of any firm level social investment programs. It is argued that organisations as social entities will be less vulnerable to social investment prejudices if external beneficiaries are enrolled into the feedback loop. Therefore a framework focused on outside in approach will provide a more kaleidoscopic view of the impact of social investment programs. The model proposes that such an approach will induce more social choice investments within the constraints of the firm. Hence ultimately reaching out to the internal and external beneficiaries in one hand and providing for a constant feedback for better social engagement programs in the other.

\section{The Analysis from the Business Trends in CSR}

A look at top 35 companies of India (Refer table 1) reveals that only 6 or $15 \%$ of the companies spend more than $2 \%$ of their profits ( $\%$ of PAT) which is quite surprising given the fact that companies have long been claiming on its social investment programs and their commitment to meeting the social objectives. Whereas the companies bill 2013 mandates $2 \%$ compulsory contribution from the profits after tax, which amounts to close to 8,000 crores (Refer to table 2) alone from the top 500 companies. Yet it is ironical that most spending companies predominantly spend on two social activities education and health (Refer to table 3) while ignoring most other social investment opportunities, therefore leading to imbalanced social priorities. At the same time to accomplish its CSR mission only 11 out of top 100 companies have their own foundations to carry out their CSR activities (Refer to table 4). The figures analysed above is far below the expectations of the current social needs. The companies need to have far more holistic input mechanisms in its CSR programs.

Table 1. CSR Activities of Top 10 Companies of India.

\begin{tabular}{|c|c|c|}
\hline Sr. NO \& Rank & Company & CSR Activities \\
\hline 1 & Indian Oil corporation limited & $\begin{array}{l}\text { One time LPG connection scheme for rural households, developing tourist amenities at } \\
\text { major tourist spots, sanitation, health care, scholarship scheme \& environment protection. }\end{array}$ \\
\hline 2 & Reliance Indusries & $\begin{array}{l}\text { Education, Community healthcare, Community safety initiative, Community environment } \\
\text { initiative, Rural development, Livelihood support program, }\end{array}$ \\
\hline 3 & $\begin{array}{l}\text { Bharat Petroleum Corporation } \\
\text { Limited }\end{array}$ & $\begin{array}{l}\text { Rural Health, Community development, Education, Social enablement, Water conservation, } \\
\text { Health, Women Empowerment, Child grooming, Women empowerment, Safety education }\end{array}$ \\
\hline 4 & $\begin{array}{l}\text { Hindustan Petroleum Corporation } \\
\text { Limited }\end{array}$ & $\begin{array}{l}\text { Vocational training, Rural retail scheme for petroleum products, Community kitchen } \\
\text { program, Rural Health, Girl child scheme }\end{array}$ \\
\hline 5 & Tata Motors & Rural and community health, Rural education, \\
\hline 6 & Oil and Natural Gas Company & Health, Education, Employability, Environment \\
\hline 7 & State Bank of India & $\begin{array}{l}\text { Assistance in Government programs, Health care, Sanitation, Drinking water project, } \\
\text { Rural energy }\end{array}$ \\
\hline 8 & Tata Steel & $\begin{array}{l}\text { Community Health, Preservation of tribal culture, Sustainable livelihood, Healthcare, } \\
\text { Employment, Employability, Empowerment \& Sports }\end{array}$ \\
\hline 9 & Punjab National Bank & $\begin{array}{l}\text { Sustainability, Corporate volunteering, Rural self employment training, Health, Social } \\
\text { collaboration }\end{array}$ \\
\hline 10 & Hindalco & $\begin{array}{l}\text { Trusteeship, Education, Health care, Sustainable livelihood, Infrastructure Development, } \\
\text { Water and sanitation }\end{array}$ \\
\hline
\end{tabular}


Table 2. CSR Activities and Performance of Top 20 Spending Companies.

\begin{tabular}{|c|c|c|c|c|c|c|c|c|c|}
\hline \multirow{2}{*}{$\begin{array}{c}\text { S. } \\
\text { No/R } \\
\text { ank }\end{array}$} & \multirow[b]{2}{*}{$\begin{array}{l}\text { Name of the } \\
\text { company }\end{array}$} & \multirow[b]{2}{*}{$\begin{array}{c}\text { Financial } \\
\text { Year }\end{array}$} & \multicolumn{3}{|c|}{ CSR Expenses } & \multicolumn{4}{|c|}{ Implementation } \\
\hline & & & $\begin{array}{l}\text { Turnover } \\
\text { (in Crores }\end{array}$ & $\begin{array}{l}\text { PAT (in } \\
\text { Crores }\end{array}$ & $\begin{array}{l}\text { CSR \% } \\
\text { of PAT }\end{array}$ & $\begin{array}{l}\text { CSR Amount } \\
\text { (in Crores) }\end{array}$ & $\begin{array}{c}\text { Own } \\
\text { Foundation }\end{array}$ & $\begin{array}{c}\text { Through } \\
\text { NGO }\end{array}$ & $\begin{array}{c}\text { Transparency } \\
\text { Score }\end{array}$ \\
\hline & Reliance & & & & & & & & 10 \\
\hline 1 & $\begin{array}{l}\text { Industries } \\
\text { Limited }\end{array}$ & $2012-2013$ & 371,119 & 21,003 & $1.70 \%$ & 357.05 & Yes & Yes & \\
\hline 2 & $\begin{array}{l}\text { Coal India } \\
\text { Limited }\end{array}$ & $2012-2013$ & 77,049 & 17,356 & $0.87 \%$ & 150.91 & No & Yes & 10 \\
\hline 3 & Tata Steel & 2011-2012 & 134,473 & 4,949 & $2.95 \%$ & 146.00 & Yes & Yes & 5 \\
\hline 4 & $\begin{array}{l}\text { State Bank of } \\
\text { India }\end{array}$ & $2012-2013$ & 135,691 & 14,105 & $0.87 \%$ & 123.33 & No & No & 10 \\
\hline 5 & ONGC & 2011-2012 & 76,887 & 25,123 & $0.48 \%$ & 121.00 & No & Yes & 8 \\
\hline 6 & $\begin{array}{l}\text { ICICI Bank } \\
\text { Limited }\end{array}$ & $2012-2013$ & 48,421 & 8,325 & 1.40 & 116.55 & Yes & Yes & 10 \\
\hline 7 & $\begin{array}{l}\text { HDFC Bank } \\
\text { Limited }\end{array}$ & $2012-2013$ & 42,993 & 15,491 & $0.58 \%$ & 89.85 & No & Yes & 7 \\
\hline 8 & $\begin{array}{l}\text { Jindal Steel } \\
\text { limited }\end{array}$ & 2011-2012 & 8,823 & 180 & $\mathrm{NC}$ & 88.00 & Yes & Yes & 5 \\
\hline 9 & ITC & $2012-2013$ & 41,810 & 7,418 & $1.11 \%$ & 82.34 & No & Yes & 10 \\
\hline 10 & IOCL & $2012-2013$ & 414,909 & 5,005 & $1.60 \%$ & 80.08 & Yes & Yes & 10 \\
\hline 11 & TCS Limited & $2012-2013$ & 64,168 & 13,917 & $0.51 \%$ & 71.60 & Yes & Yes & 10 \\
\hline 12 & $\begin{array}{l}\text { Larsen \& } \\
\text { Toubro }\end{array}$ & 2011-2012 & 65,142 & 4,691 & $1.49 \%$ & 70.00 & Yes & No & 5 \\
\hline 13 & SAIL & 2011-2012 & 48,263 & 3,593 & $1.78 \%$ & 64.00 & Yes & Yes & 8 \\
\hline 14 & $\begin{array}{l}\text { NMDC } \\
\text { Sterlite }\end{array}$ & 2011-2012 & 13,278 & 7,265 & $0.87 \%$ & 63.32 & No & Yes & $\begin{array}{l}8 \\
5\end{array}$ \\
\hline 15 & $\begin{array}{l}\text { Industries } \\
\text { Limited }\end{array}$ & 2011-2012 & 44,342 & 7,761 & $0.74 \%$ & 57.58 & Yes & Yes & \\
\hline 16 & GAIL & 2011-2012 & 40,830 & 3,654 & $1.48 \%$ & 54.00 & Yes & No & 2 \\
\hline 17 & NTPC & 2011-2012 & 68,831 & 9,815 & $0.50 \%$ & 49.07 & Yes & Yes & 8 \\
\hline 18 & $\begin{array}{c}\text { AXIS Bank } \\
\text { Ambuja }\end{array}$ & $2012-2013$ & 33,734 & 5,179 & $0.82 \%$ & 42.42 & Yes & Yes & $\begin{array}{c}7 \\
10\end{array}$ \\
\hline 19 & $\begin{array}{l}\text { Cement } \\
\text { Limited }\end{array}$ & 2011-2012 & 9,675 & 1,297 & $3.01 \%$ & 39.08 & Yes & Yes & \\
\hline 20 & $\begin{array}{l}\text { Bharati } \\
\text { Enterprises } \\
\text { Limited }\end{array}$ & 2011-2012 & 42,229 & 5,730 & $0.58 \%$ & 33.00 & Yes & No & 5 \\
\hline
\end{tabular}

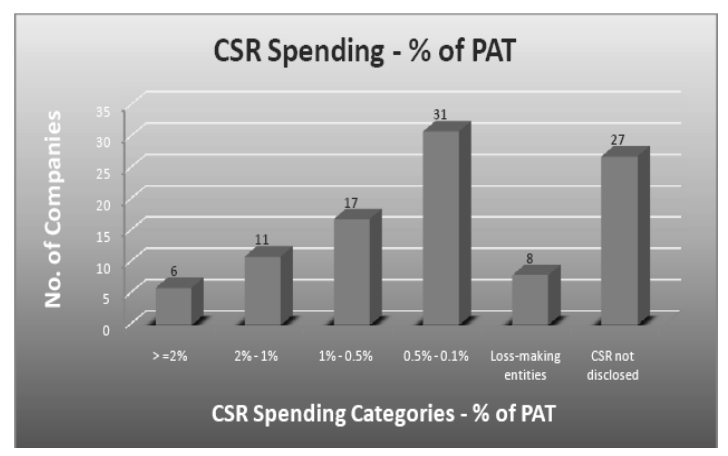

Figure 2. CSR Spending of Top 35 Companies.

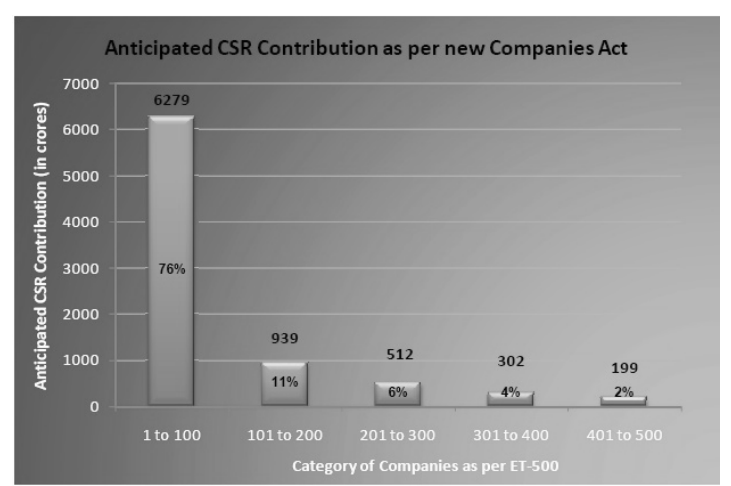

Figure 3. Tentative Outlay for CSR Activities Envisaged by New Companies Act, 2013.

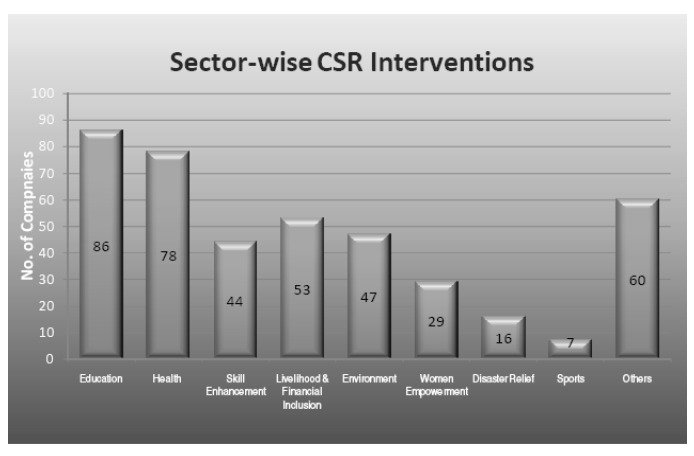

Figure 4. Sector Specific CSR Spending by 35 Top Indian Companies.

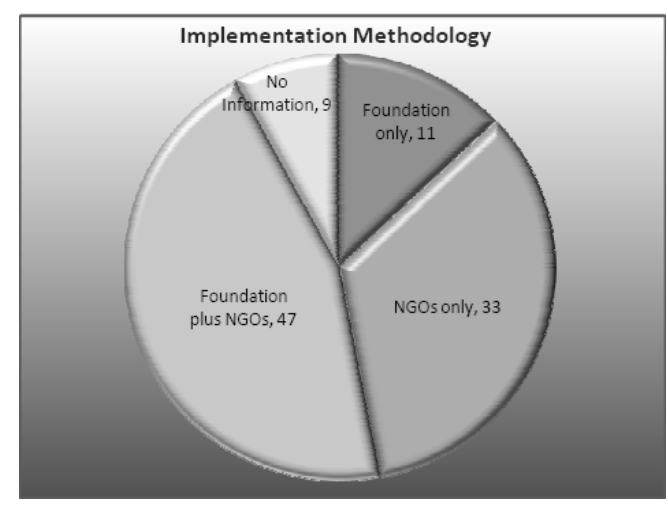

Figure 5. Channel of Implementation of CSR Activities by Top 100 Indian Companies. 


\section{Conclusion}

To conclude, stakeholder theory suggests that firms are motivated to broaden their objectives to include other goals in addition to profit maximization. Motivation for satisfying stakeholder demands stems from the fact that addressing stakeholder needs can be correlated with a firm's survival, economic well-being, competitive advantage, and the development of trust and loyalty among its targeted customers (Mitchell et al., 1997). While ample evidence exists supporting the idea that companies that invest in CSR will achieve positive benefits across all stakeholder groups, therefore, managers can adopt a specific category of CSR program contingent on the desire

It may thus be concluded that the future of organizations largely depends on the kind of social investment choices they make and the partners involved in the decision making process of such investments. Stakeholder theory (Freeman, 1984) suggests the idea that investing time and other resources in addressing stakeholders' interests is a justifiable managerial activity. Therefore for managers and firms seeking to serve the social mandate must adopt a multi stakeholder participation in its social investment plans and processes.

\section{References}

[1] Arnstein, S.R. (1969). A ladder of citizen participation.American Institute of Planners, July, 216-224. Retrieved from http://lithgow-schmidt.dk/sherryarnstein/ladder-of-citizen-participation.html

[2] Bowen, H. R. (1953). Social Responsibilities of the Businessman. Harper \& Row: New York.

[3] Bowmann-Larsen, L. and O. Wiggen. (2004), Responsibility in World Business: Managing Harmful Side-Effects of Corporate Activity (United Nations University Press, USA).

[4] Brammer, S. and S. Pavelin. (2004), 'Building a Good Reputation', European Management Journal 22(6), 704-713.

[5] Burke, L. and J. M. Logsdon. (1996), 'How Corporate Social Responsibility Pays Off ', Long Range Planning 29(4), 495-502.

[6] Carroll, A. and A. Buchholtz. (2003), Business and Society, Ethics and Stakeholders Management, 5th Edition (Thomson, Mason (Ohio)).

[7] Carroll, A. B. (1979), 'A Three-Dimensional Model of Corporate Performance', Academy of Management Review 4(4), 497-505.

[8] Carroll, A. B. (1991), 'The Pyramid of Corporal Social Responsibility: Towards the Moral Management of Organisational Stakeholders', Business Horizons Jul? Aug, $39-48$.

[9] Castka, P., et al. (2004), 'How can SMEs Effectively Implement the CSR Agenda? A UK Case Study Perspective', Corporate Social Responsibility and Environmental Management 11, 140-149.
[10] Clarkson, M.: 1995, 'A Stakeholder Framework for Analyzing and Evaluating Corporate Social Perfor mance', Academy of Management Review 20(1), 92117.

[11] Commission of the European communities, (2006). Communication from the Commission to the European Parliament, the Council and European Economic and Social Committee, Implementing the partnership for growth and jobs: Making Europe a pole of Excellence on Corporate Social Responsibility. [March] Brussels Retrieved from http://eurlex.europa.eu/LexUriServ/LexUriServ.do?uri=CO M:2006:0136:FIN:EN:PDF (May 10, 2010)

[12] Daniels, J. and L. Radebaugh. (2001), International Business: Environments and Operations (Prentice Hall Inc., New Jersey).

[13] Department for Business Innovation and Skills [DBIS], (2009). The Benefits of Regulation: A public and business perceptions study. October 2009, URN 09/1403. Retrieved from http://www.bis.gov.uk/files/file53236.pdf ( February 14, 2011)

[14] Deresky, H. (2000), International Management: Managing Across Boarders and Cultures (Prentice Hall Inc., New Delhi)

[15] Dunfee, T. W. (1991), 'Business Ethics and Extant Social Contracts', Business Ethics Quarterly 1(1), 23-51. doi: $10.2307 / 3857591$.

[16] Elsbach K. D. (1994). Managing organizational legitimacy in the California cattle industry: The construction and effectiveness of verbal accounts', Administrative Science Quarterly 39:57-88. http://dx.doi.org/10.2307/2393494

[17] Epstein, E. M. (1989). Business ethics, corporate good citizenship and the corporate social policy process: A view from the United States. Journal of Business Ethics, 8(8), 583-595.

[18] Epstein, M. and M. Roy: (2001), 'Sustainability in Action: Identifying and Measuring the Key Performance Drivers', Long Range Planning 34, 585-604.

[19] European Commission (2001).Promoting a European framework for Corporate Social Responsibility: green paper. Luxembourg: Office for official publication of the European Communities

[20] Fairbrass, J. (2006), 'UK Businesses and CSR Policy: Shaping the Debate in the EU',Working Paper 06/31, School of Management, University of Bradford. October 2006.

[21] Freeman, R. E. (1984), Strategic Management: A Stakeholder Approach (Pitman Publishing Inc., Massachusetts).

[22] French, P. A. (1984). Collective and corporate responsibility. New York: Columbia University Press.

[23] Gatto, Alexander C. (2002). The European Union and Corporate Social Responsibility: Can the E U contribute to the Accountability of Multinational Enterprise? Institute of International Law, Working Paper No 32 September. retrieved from https:/www.law.kuleuven.be/iir/nl/onderzoek/wp/WP32e.pd f ( February 14,2011)

[24] Glaser E., \& Gyourko J. (2002). Zoning's steep prices. Regulation, Fall 
[25] Greenfield, W. M. (2004), 'In the Name of Corporate Social Responsibility', Business Horizons 47(1), 19-28.

[26] Hasnas, J. (1998), 'The Normative Theories of Business Ethics: A Guide for the Perplexed', Business ethics Quarterly 8(1), 19-42. doi:10.2307/3857520.

[27] Hofstede, G. (1997), Cultures and Organisations: Software of the Mind - Intercultural Cooperation and Its importance for Survival (McGraw-Hill, New York, USA).

[28] Jones, T. M. and A. C. Wicks. (1999), 'Convergent Stakeholder Theory', The Academy of Management Review 24(2), 206-221.

[29] Jones, T. M. (1980), 'Corporate Social Responsibility Revisited, Redefined', California Management Review 22(3), 59-67.

[30] Maignan, I. and O. Ferrell: (2003), 'Nature of Corporate Responsibilities: Perspectives from American, French, and German Consumers', Journal of Business Research 56, 55-67.

[31] Maignan, I., et al. (2002), 'Managing Socially Responsible Buying: How to Integrate Non-Economic Criteria into the Purchasing Process', European Management Journal 20(6), 641-648.

[32] McGuire J. W. (1963). Business and Society. New York, McGraw Hill

[33] Muller, A. (2006), 'Global Versus Local CSR Strategies', European Management Journal 24(2-3), 189-198.

[34] Murray, K.B. and Vogel, C.M. (1997) 'Using a Hierarchy-of Effects Approach to Gauge the Effectiveness of Corporate Social Responsibility to Generate Goodwill Toward the Firm: Financial versus Non financial Impacts'. Journal of Business Research. Vol. 38, 141-159

[35] O'Riordan, L. and J. Fairbrass. (2006), 'Corporate Social Responsibility (CSR). Models and Theories in Stakeholder Dialogue', Working Paper 06/45, School of Management, University of Bradford, November 2006.

[36] Phillips, R. A. (2003). Stakeholder theory and organization ethics. San Francisco: Berrett-Koehler. Powell, W. W., \& P. J. DiMaggio (eds.), (1991).The New Institutionalism in Organizational Analysis. University of Chicago, Chicago

[37] Pritchard A. C.(2003). Self-Regulation and Securities Markets. Regulation, Spring

[38] Shaxson, N. (2009). Nigeria Extractive Industries Transparency Initiative: Just a glorious audit? Chatham House.Retrieved from http://www.chathamhouse.org.uk/files/15223_1109neiti.pdf ( December 28, 2009)

[39] Soares, C. (2003). Corporate versus individual moral responsibility. Journal of Business Ethics, 46(2), 43-150.

[40] Trompenaars, F. and C. Hampden-Turner. (2004), Riding the Waves of Culture: Understanding Cultural Diversity in Business, 3rd Edition (Nicholas Brealey Publishing, London).

[41] Tuzzolino, F., \& Armandi, B. (1981). A Need Hierarchy Framework for Assessing CSR. American Management Review 6 21-28, p 24 USA).
[42] Utting, P., (2005). Rethinking Business Regulation: From Self-Regulation to Social Control Technology. Business nd Society Programme Paper, Number 15, September

[43] Weiss, J. W. (1998), Business Ethics: A Stakeholder and Issues Management Approach (Dryden Press, Forth Worth)

[44] Welford, R. (2004), 'Corporate Social Responsibility in Europe and Asia: Critical Elements and Best Practice', Journal of Corporate Citizenship 13, 31-48.

[45] Welford, R. (2005), 'Corporate Social Responsibility in Europe, North America and Asia', Journal of Corporate Citizenship 17, 33-52.

[46] Wettstien F. (2009). Beyond voluntariness, beyond CSR: Making a case for human rights and justice Business and Society Review 114:1 125-1

[47] Wood, D. (1991), 'Corporate Social Performance Revisited', Academy of Management Review 16(4), 691-718.

[48] Woodward, D., et al. (2001), "Some Evidence on Executives". Views of Corporate Social Responsibility", British Accounting Review 33, 357-397.

[49] Argandona, A.: 1998, 'The Stakeholder Theory and the Common Good', Journal of Business Ethics 17(9/10), 10931102.

[50] Harvey, B. and A. Schaefer: 2001, 'Managing Relation ships with Environmental Stakeholders: A Study of U. K. Water and Electricity Utilities', Journal of Business Ethics 30(3), 243-260.

[51] Post, F. R.: 2003, 'A Response to "the Social Respon sibility of Corporate Management: A Classical Cri tique"', MidAmerican Journal of Business 18(1), 25-35.

[52] Ullmann, A.: 1985, 'Data in Search of a Theory: A Critical Examination of the Relationship among Social Perfor mance, Social Disclosure and Economic Performance', Academy of Management Review 10(3), 540-577.

[53] Pesqueux, Y. 2011b. La responsabilité sociale de l'entreprise (RSE) comme discours ambigu. Innovations, (34):37-55.

[54] Palmer, D. E., \& Stoll, M. L. 2011. Moving Toward a More Caring Stakeholder Theory: Global Business Ethicsin Dialogue with the Feminist Ethics of Care. In $\mathrm{M}$. Hamington \& M. Sander-Staudt (Eds.) Applying Care

[55] Ethics to Business, 111-126. Springer.

[56] J. E. Post, L. E. Preston, and S. Sachs, Redefining the Corporation:Stakeholder Management and Organizational Wealth (Stanford: Stanford University Press, 2002).

[57] J. S. Harrison and R. E. Freeman, "Stakeholders, social responsibility and performance: Empirical evidence and theoretical perspectives," Academyof Management Journal 42, 5(1999): 479-485; H. Mintzberg, "Thecase for corporate social responsibility," Journal of Business Strategy 4, 2(1983): 3-15.

[58] Mitchell, R.K., Agle, B.R. and Wood, D.J. 1997.'Toward a theory of stakeholder identification and salience: defining the principle of who and what really counts'. Academy of Management Review, 22:4, 853-886. 